\title{
Technological Pedagogical Content Knowledge (TPACK) and the Teaching of Science: Determiners for Professional Development
}

\author{
JOSHUA CASELEY ANAK AKUN ${ }^{1}$, FITRI SURAYA MOHAMAD² \\ ${ }^{1}$ Sarawak State Education Department, MALAYSIA \\ ${ }^{2}$ Faculty of Cognitive Sciences and Human Development, UNIVERSITI MALAYSIA SARAWAK, KOTA SAMARAHAN, \\ MALAYSIA.E-mail: mfitri@unimas.my
}

\begin{abstract}
The study investigates how Science teachers articulate their self-confidence in teaching Science with technology. Technological Pedagogical Content Knowledge (TPACK) is used as the primary tool to describe their practice. Using a quantitative approach, with an initial survey of 408 science teachers from 59 secondary schools in a state in East Malaysia, descriptive and inferential statistics were conducted to assess science teachers' level of TPACK and discriminate differences between perceptions on TPACK related to their teaching experience. Findings revealed that the level of Content Knowledge (CK), Pedagogical Knowledge (PK), Technological Knowledge (TK) and Pedagogical Content Knowledge (PCK) are high, in comparison to their Technological Content Knowledge (TCK), Technological Pedagogical Knowledge (TPK) and Technological Pedagogical Content Knowledge (TPACK) which were recorded at a moderate level. The study also found how teachers with more extensive experience teaching reported higher confidence with their CK, PK and PCK. Novice teachers indicated slightly higher confidence in their TK. The study provides a set of determiners for professional development opportunities for Sarawak Science teachers to upskill their knowledge to integrate science content, pedagogy, and technology.
\end{abstract}

Keywords: Science teaching, Technological Pedagogical Content Knowledge, Secondary Education

JEL Classification: C1, L2 


\section{Introduction}

The learning of Science is often considered to be challenging, complex and complicated to understand. It has become commonplace for students to pass the exam by memorising algorithms only while failing to build an understanding of scientific concepts and schemes in science learning (Dhanapal \& Wan, 2014). Memorising facts is in direct contrast to science subject learning objectives which focus on the mastery of elements such as scientific process skills, thinking skills, problem-solving and the ability to use higher-order thinking. The learning of Science should trigger a student's critical and creative thinking skills through active involvement in learning. To achieve this, the science teacher needs to be wise in determining the pedagogical aspects relevant to the science content taught. Also, science teachers need to use teaching aids that can help students forge sufficient understanding of the learning contents.

The use of technology is emphasised in the teaching and learning process of Science (Guzey \& Roehrig, 2009). Technology has a strong positive potential to change the teaching and learning environment when it is used in the right way (Crawford, 2000; Dilworth et al., 2012). Hence, the concept of using technology in the science classroom should be based on the principle of problemsolving rather than just being used as a substitute for existing teaching method (Ghavifekr \& Wan Athirah, 2015). The use of technology is essential to complement the contents of science lessons as well as to solve the teaching and learning problems in the classroom.

Science teachers make instructional decisions that significantly impact the learning of their students. Some of these decisions pertain to the modification of curriculum, while others may affect the use of technology in instruction. Instructional approaches and strategies are primarily influenced by teachers' Technological Pedagogical Content Knowledge (TPACK). With sufficient knowledge of each TPACK component, teachers become competent, flexible, dynamic and adaptive in producing effective teaching with technology (Koehler and Mishra, 2009). Many previous studies have suggested that teachers often consider technology knowledge in isolation from content knowledge (Mohamad, 2010; Pamuk, 2012; Carpenter et al., 2020). The perception has led to a limited effort to diversify instructional strategies to incorporate the optimal use of technology to enhance instructional quality. Teachers, in general, are trained for pedagogical knowledge, and they generally learn about technology; however, many do not utilise their knowledge in tandem with their knowledge about their subject matter (Mohamad, 2010).

The TPACK framework enables teachers to view what they know as a teacher (Graham et al., 2009). Developing TPACK is a strategy to address challenges teachers typically face when aligning current demands in learning with subject content delivery (Olafson, Swallow, Neumann, 2016). By strengthening their TPACK, teachers have a chance to use technology in teaching and learning process efficiently (Cheng and Xie, 2018).

In Malaysia, research on TPACK as a professional development tool for teachers are few and far between. For example, a study by Muhammad Abd Hadi \& Fatin Aliah (2012) only focused on identifying TPACK among undergraduate physics education degree students. Nurul Ain and Zaleha (2008) identified the attitudes and belief of teacher trainees on the Mathematic TPACK elements. Mohamad (2010) analysed how teacher training programmes at local universities addressed the use of TPACK and found the discrepancies between intention and action among teacher educators and their student teachers. A study by Hasniza \& Tengku Faekah (2016) focused on the validation of TPACK instrument using ICT in teaching and learning for pre-service teachers.

At a macro level, the Ministry of Education Malaysia has consistently provided technology infrastructure for schools across the country. However, there is yet systematic longitudinal evidence that evaluates the effectiveness of technology use in classroom teaching, particularly on how it aids the development of higher-order thinking skills among Malaysian students. However, there has been much small-scale research which indicated how teachers are not ready to integrate technology with subject content and pedagogical strategies (Hew \& Brush, 2007; Tunku Badariah, 2014; Wachira \& Keengwe, 2010). 
Another aspect which lacked investigation is on the relationship between teachers' demographic profile and TPACK perceptions. Jang and Tsai (2013) and Koh et al. (2014) discovered that there are significant differences between teachers' TPACK and their teaching experiences. They found that those who have more years of teaching experiences are more likely have higher confidence on their Content Knowledge (CK), Pedagogical Knowledge (PK) and Pedagogical Content Knowledge (PCK) when compared to novice teachers. However, they also found that experienced teachers are less likely to be confident in using technological knowledge. Teo and Hwee (2010) also reported that computer use attitudes among teachers in their study were influenced by age, gender, and the level at which the teachers are teaching.

These gaps indicated the need for an investigation into issues of how Sarawak teachers cope with the teaching of Science, where they are challenged by geographical distribution and diverse student demographics. Although Sarawak schools have been receiving technology infrastructure and tools to aid classroom teaching, the use of technology has been poles apart between those in urban and rural locations.

\section{TPACK and Science Teachers in Sarawak}

In the past decade, Technological Pedagogical Content Knowledge (TPACK) has been researched and referred to as a seminal conceptual framework on teacher knowledge. It is referenced as a model to determine technology integration within the context of teacher education. TPACK is described as a multifarious interaction of content, pedagogy and technology; it triggers well-evidenced debate and discussion on the successful integration of technology into instruction (Koehler \& Mishra, 2009). TPACK has been extensively discussed within the framework by Shulman's $(1986,1987)$ description of Pedagogical Content Knowledge (PCK). According to Shulman (1986), PCK "goes beyond the knowledge of subject matter per se to the dimension of subject matter knowledge for teaching", thus being the relationship between pedagogy and content knowledge. By adding the technology component into the discussion, TPACK initiates a perspective to look into how teachers use technology to extend the knowledge of teaching and content. TPACK attempts to dissect how teachers understand educational technologies to produce effective teaching.

There are seven types of knowledge within the TPACK framework. The definition of each is shown below on the basis previous studies (Cox \& Graham, 2009; Graham et al., 2009; Koehler \& Mishra, 2009; Liang et al., 2013).

$$
\begin{array}{cc}
\text { Technological } \\
\text { Knowledge (TK) }
\end{array}
$$

3 Content Knowledge (CK)

$4 \quad$ Pedagogical Content Knowledge (PCK)

5 Technological Content Knowledge (TCK)

6 Technological Pedagogical Knowledge (TPK)

7 Technological Pedagogical Content Knowledge (TPACK)
The general knowledge of digital and emerging technologies, such as using interactive mobile tools.

The general knowledge of how to teach; it includes principles of instruction, the psychology of students, classroom management and teaching strategies.

In this study, the knowledge of the science subject content is the focus.

The knowledge of adopting pedagogical strategies to foster students' understanding of the content of science subject.

The knowledge to represent the science content subject with digital technologies.

The knowledge of the presence, components, and capabilities of various digital technologies which are used for teaching

The knowledge of using technologies to teach and represent the science content subject 
In TPACK, the dynamic nature of interactions between CK, PK and TK make them dependent on each other. To be able to teach effectively using technology, the knowledge to choose the appropriate tools determines the success of a lesson. Inquiry-based learning, a fundamental approach in the teaching of Science, requires teachers to have a level of knowledge to integrate content knowledge, pedagogy and technology seamlessly in the teaching process. TPACK has enabled many conversations in numerous teacher education programmes, and restructuring of content priorities according to components within TPACK has been implemented (Niess, 2005; Niess et al., 2009).

Why do we need to study in-service teachers? The majority of reported TPACK studies concentrate on pre-service teachers (Mouza, 2016). In-service teachers have not been extensively investigated (Chen and Jang, 2016). The gap in research entails a concern about the ability of teachers to dynamically align their knowledge in teaching to meet emerging demands in learning. For example, in the Covid-19 pandemic at the time of writing, where teachers are unnaturally obligated to find alternative means to teach remotely, the use of technology to teach immediately came under scrutiny. Previous research has suggested how in-service teachers, specifically those with long teaching experiences, tended to view their Technological Pedagogical Content Knowledge as being lower than did teachers with less teaching experience (Lee \& Tsai, 2010). Although Jang \& Tsai (2012) described in their study that teachers with more teaching experience showed higher in CK and PCK than did teachers with less teaching experience, when being positioned in a context where remote teaching is the only way to deliver instruction, the competency to acknowledge the TPACK components is even more critical. Therefore, this study aims to determine if Science teachers in Sarawak hold differing competencies in teacher knowledge, using the TPACK framework as the critical point of reference and if their teaching experience makes any distinction to the use (or non-use) of technology to teach Science.

There have also been numerous attempts to assess teachers' TPACK development using the model (Koehler \& Mishra, 2005). Quantitative approaches have been deployed for several purposes including measuring the level of TPACK among teachers, assessing the outcome of an intervention program based on the TPACK concept, testing the validity of TPACK knowledge constructs and examining interaction relationships between TPACK knowledge components. Researchers often use survey methods that involve collecting data through questionnaires that contain knowledge related items integrating technology during the teaching and learning process (Koehler et al., 2012).

The early stages of quantitative measurement in TPACK research focused on developing a questionnaire that can measure each component or construct of TPACK knowledge (Chai et al., 2011; Koehler \& Mishra, 2005; Schmidt et al., 2009). These instruments were then used to collect data on teacher self-evaluation of TPACK. Schmidt et al. (2009) constructed a 58-item Survey of Preservice Teachers' Knowledge of Teaching and Technology. It measured pre-K-6 teachers' general perceptions of TPACK for content areas of mathematics, social studies, Science and literacy. TPACK surveys for specific areas have also been developed, for instance, one by Graham et al. (2009) who developed a 30-item TPACK in Science teaching survey to measure teachers' TPACK levels.

\section{Methodology and Materials}

The present study employs a quantitative approach, in which a survey was constructed to capture on-the-ground issues faced by teachers in using technology in their classrooms. The survey elicits responses on teacher attitudes, perceptions, beliefs, feelings, and behaviours.

In-service teachers from the southern zone of Sarawak, specifically Kuching, Samarahan, Simunjan, Serian, Lundu, Bau and Padawan divisions, were invited to participate in the study. The participants' teaching experience ranged from 1 year to above 21 years. The disciplines they taught included general sciences for Form 1 until Form 5. From the onset, it was clear that the instrument for the study was relevant to the target group of participants. Demographically, they represent Science teachers who are teaching at urban, semi-urban and semi-rural schools in Sarawak Borneo. 
Using the Survey of Pre-service Teachers' Knowledge of Teaching and Technology developed by Schmidt et al., (2009) and Graham et al., (2009), which were used to survey science teachers' selfreported confidence in TPACK, this study adopted and modified Schmidt et al.'s survey to measure selfreported TPACK confidence levels among the secondary school science teachers in the selected demography. Each statement in the modified survey was rated as a seven-point Likert-type scale, ranging from Strongly disagree to Strongly agree.

The survey was manually distributed to 52 selected secondary schools in Sarawak. Permission was obtained from the State Education Department and every school principal, before the study. Science teachers were approached to invite them to participate in the survey. Informed consent was included to ensure voluntary participation and anonymity. Data screening was performed, to eradicate responses which are returned in the form of linear patterns, straight-lining and those which were incomplete would be omitted. After the screening process, only 408 survey forms were categorised as valid for data analysis.

IBM SPSS was used to identify the values of self-reported levels of Technological Pedagogical Content Knowledge (TPACK) among participants. Table 1.0 shows the interpretation of mean scores proposed by Lin et al. (2013).

Table 1 Interpretation of Mean Scores for Levels of Self Confidence

\begin{tabular}{ll}
\hline Interval Range & Levels of self-confidence \\
\hline $1.00-3.00$ & Low \\
$3.01-5.00$ & Moderate \\
$5.01-7.00$ & High \\
\hline
\end{tabular}

Rating scores were compared for every factor between participant groups. Categories were defined according to their demographic characteristics. ANOVA was used to discriminate differences between perceptions of Science teachers on TPACK, and the values were analysed based on their reported length of teaching experience.

\section{Results}

A total of 408 secondary school Science teachers from 52 public schools participated in this survey. Table 2.0 shows the demographic profile of participants.

Table 2 Demographic profile

\begin{tabular}{lcc}
\hline Profile & Frequency & Percentage \\
\hline Sex & 117 & \\
Male & 291 & 28.7 \\
Female & & 71.3 \\
Academic Qualification & 23 & \\
Diploma & 323 & 5.6 \\
Degree & 62 & 79.2 \\
Master's degree & & 15.2 \\
Teaching Experience (Year) & 48 & \\
$1-5$ & 105 & 11.8 \\
$6-10$ & 88 & 25.7 \\
$11-15$ & 103 & 21.6 \\
$16-20$ & 64 & 25.2 \\
21 and above & & 15.7 \\
\hline
\end{tabular}

Table 3.0 presents the mean scores for seven TPACK constructs. The analysis shows how the Science teachers' mean scores for all constructs are beyond 5 points (more than midway of the 7-point scale), except for TCK, TPK and TPACK. Of the seven constructs on the TPACK survey, the highest scores were recorded on CK, followed by TK, PK and PCK. The participants scored relatively moderately on TPK, TCK 
and TPACK. The analysis also implies that the highest agreement lies in their perceived capability in Science content subject (CK), general knowledge of digital technologies (TK), general knowledge of instruction (PK) and how to use proper instruction to teach the intended the science content subject (PCK). However, the lower values recorded for TPK, TCK and TPACK imply an indication toward a degree of doubt or uncertainty about the adequacy of their levels of knowledge to use technology to teach Science.

Table 3 Mean and Standard Deviation values for TPACK constructs
TPACK Construct
$\mathbf{N}$
Mean
Standard Deviation

\begin{tabular}{lllll}
\hline 1. & CK & 408 & 5.42 & 0.85 \\
2. & PK & 408 & 5.24 & 0.81 \\
3. & TK & 408 & 5.37 & 0.82 \\
4. & PCK & 408 & 5.21 & 0.93 \\
5. & TCK & 408 & 4.65 & 1.03 \\
6. & TPK & 408 & 4.70 & 1.01 \\
7. & TPACK & 408 & 4.37 & 1.13 \\
\hline
\end{tabular}

Does the length of teaching experience affect the teachers' reported knowledge levels in TPACK? Table 4.0 illustrates how there is statistical significance in CK, PK, TK, PCK and TPACK components when compared with years of teaching experience in Science. To examine every component, science teachers who have more extensive teaching experience tended to rate their CK, PK and PCK levels significantly higher than that of novice teachers. Alternatively, those with minimal teaching experiences were more likely to rate their TK as significantly higher than those who are more experienced in teaching Science. The mean plot generated from the data indicated a sharp downward trend in TK, TPK, TCK and subsequently TPACK values, when input was compared between the five groups of participants (based on years of teaching experience).

Table 4 Means, standard deviation and ANOVA values for TPACK constructs

\begin{tabular}{|c|c|c|c|c|c|c|c|c|c|c|c|}
\hline \multirow[t]{2}{*}{ Component } & \multicolumn{2}{|c|}{$\begin{array}{c}1-5 \\
(n=48)\end{array}$} & \multicolumn{2}{|c|}{$\begin{array}{c}6-10 \\
(n=105)\end{array}$} & \multicolumn{2}{|c|}{$\begin{array}{c}11-15 \\
(n=88)\end{array}$} & \multicolumn{2}{|c|}{$\begin{array}{c}16-20 \\
(n=103)\end{array}$} & \multicolumn{2}{|c|}{$\begin{array}{c}>21 \\
(n=64)\end{array}$} & \multirow[b]{2}{*}{$\mathrm{F}$} \\
\hline & $M$ & $S D$ & $M$ & $S D$ & $M$ & $S D$ & $M$ & $S D$ & $M$ & $S D$ & \\
\hline CK & 4.91 & .92 & 5.25 & .95 & 5.47 & .68 & 5.56 & .79 & 5.77 & .68 & $9.520 * * *$ \\
\hline PK & 4.82 & .78 & 5.16 & .84 & 5.17 & .80 & 5.41 & .70 & 5.53 & .80 & $7.230 * * *$ \\
\hline TK & 5.58 & 1.00 & 5.54 & .96 & 5.37 & .90 & 5.26 & .81 & 5.09 & .99 & $3.409 * *$ \\
\hline PCK & 4.77 & .71 & 5.07 & .88 & 5.19 & .75 & 5.36 & .72 & 5.53 & .81 & $8.091^{* * *}$ \\
\hline TCK & 4.66 & .97 & 4.81 & 1.07 & 4.70 & 1.00 & 4.55 & 1.00 & 4.48 & 1.10 & 1.379 \\
\hline TPK & 4.62 & .82 & 4.85 & 1.03 & 4.65 & 1.07 & 4.74 & .97 & 4.53 & 1.06 & 1.261 \\
\hline TPACK & 4.24 & 1.03 & 4.59 & 1.19 & 4.25 & 1.24 & 4.47 & 1.04 & 4.09 & 1.02 & $2.647^{* *}$ \\
\hline
\end{tabular}

Table 5 illustrates the pattern of data derived from a Tukey post hoc test. There was a statistically significant difference between groups was determined by one-way ANOVA ( $F=9.520, p=0.000$ (for Content Knowledge); $F=7.230, p=.000$ (for Pedagogical Knowledge), $F=8.091, p=0.000$ (for Pedagogical Content Knowledge); $F=3.409, p=.009$ (for Technology Knowledge); and $F=2.647, p=$ 0.33 (for TPACK). A Tukey post hoc test revealed that TK and TPACK were statistically significantly lower for all groups (based on their Years of teaching experience), compared to other TPACK constructs. There was no statistically significant difference between TCK and TPK for all groups. 
Table 5 ANOVA values between TPACK values for between and within respondent groups (Based on Years of Teaching Experience)

Tukey HSD

\begin{tabular}{|c|c|c|c|c|c|c|}
\hline Component & & $\begin{array}{l}\text { Sum of } \\
\text { Squares }\end{array}$ & df & $\begin{array}{l}\text { Mean } \\
\text { Square }\end{array}$ & $\mathrm{F}$ & Sig. \\
\hline \multirow[t]{2}{*}{ CK } & Between Groups & 25.343 & 4 & 6.336 & 9.520 & $.000 *$ \\
\hline & Within Groups & 268.212 & 403 & 0666 & & \\
\hline \multirow[t]{2}{*}{ PK } & Between Groups & 17.737 & 4 & 4.434 & 7.230 & $.000 *$ \\
\hline & Within Groups & 247.161 & 403 & .613 & & \\
\hline \multirow[t]{2}{*}{ PCK } & Between Groups & 20.337 & 4 & 5.084 & 8.091 & $.000 *$ \\
\hline & Within Groups & 253.244 & 403 & .628 & & \\
\hline \multirow[t]{2}{*}{ TK } & Between Groups & 11.605 & 4 & 2.901 & 3.409 & $.009 *$ \\
\hline & Within Groups & 343.008 & 403 & .851 & & \\
\hline \multirow[t]{2}{*}{ TCK } & Between Groups & 5.848 & 4 & 1.462 & 1.379 & .241 \\
\hline & Within Groups & 427.369 & 403 & 1.060 & & \\
\hline \multirow[t]{2}{*}{ TPK } & Between Groups & 5.122 & 4 & 1.280 & 1.261 & .285 \\
\hline & Within Groups & 409.193 & 403 & 1.015 & & \\
\hline \multirow[t]{2}{*}{ TPACK } & Between Groups & 13.278 & 4 & 3.319 & 2.647 & $0.33^{*}$ \\
\hline & Within Groups & 505.457 & 403 & 1.254 & & \\
\hline
\end{tabular}

\section{Discussion}

Findings from the study revealed how in-service Secondary Science teachers in the selected schools had reported higher competency levels in CK, PK, TK and PCK components. Mean plots generated from the data also showed how CK, PK and PCK are reported to increase with the years of teaching. It correlates with the fact that these teachers have completed their bachelor's degree, and they would have received training in content and pedagogy. It aligned with Arumugam (2014) who described how teachers had been provided with the content and pedagogical knowledge while in training at teacher education institutes and public universities in the country. Such exposure provided an opportunity for teachers to learn about subject content and pedagogical knowledge, hence increasing their levels of confidence in the teaching of Science. The Ministry of Education is also consistently opening opportunities for continuous professional development to help the science teachers to master the CK and PK. According to the Curriculum Development Division, 158,768 science teachers have been trained in Higher Thinking Skills courses (Kementerian Pendidikan Malaysia, 2016). Subsequent implementations of other professional development training programmes such those tailored toward the Programme for International Student Assessment (PISA) have also been found to enhance Science content knowledge. Through such professional development courses or programmes, teachers have an opportunity to enhance and develop their teaching knowledge and competencies.

The study has found that in-service science teachers not only held higher confidence levels in their personal CK and PK levels, but they also reported a higher degree of confidence for the PCK component. The finding supports a study by Kleickmann et al., (2013) who found how teachers who rated themselves higher in CK and PK would be more likely to display higher confidence in PCK. Highly experienced in-service science teachers could help students to understand the content of Science through a variety of teaching methods. They can identify aspects of students' weaknesses and strengths in the learning process. The content and pedagogical competence enable Science teachers to determine the activities, techniques, teaching strategies and teaching aids to match students' ability and interests.

Findings of this study also support the recommendation by Graham (2011) and Mohamad (2010), who argued that TCK, TPK and TPACK components require serious attention. In this study, all three knowledge components of TCK (average for all groups $=5.3676$ ), TPK (average for all groups $=4.7034$ ) and TPACK (average for all groups $=4.3689$ ) have shown mean scores at the moderate level. The interactions between TK component with other knowledge components such as (TCK, TPK and TPACK) 
scored lower than those that did not involve interaction with TK such as PCK. Although the teachers with lesser teaching experience indicated a high value in technology knowledge, it would not guarantee the effectiveness of teacher teaching using technology. The effectiveness of technology integration also depends on the interrelationships between the content, pedagogy, and technology (Angeli \& Valanides, 2005; Cox \& Graham, 2009; Koehler \& Mishra, 2009).

Other factors that may contribute to the moderately reported values of TCK, TPK and TPACK are that teacher programmes or in-service training in educational technology do not provide sufficient knowledge about the interaction between content, pedagogy and technology (Nur Filzah, 2016). The phenomenon may be caused by a lack of a national-level policy on technology integration, which would discriminate the categories of knowledge, skills and competencies necessary for effective teaching. Teacher education institutions in the country are key players to initiate change in the approach to training teachers in the country. In Malaysia, most of the technology-based courses offered in teacher education programme are skills-based courses and taught as a stand-alone subject (Mohamad, 2010). Hence, the integration of technological knowledge into pedagogy and content is left to the teachers to shape the congruence between the three knowledge domains.

The lack of comprehensive theory and conceptual frameworks which would guide the integration of teacher knowledge components have contributed to the dissonance in technology integration among teachers in Malaysia, specifically among Sarawak Science teachers. Relevant models, theories or conceptual frameworks which address contextualised needs, abilities and goals of local teacher education could guide research and inquiry in the field of Educational technology. Research by Abbitt (2011) and Jaipal and Figg (2015) reported similar patterns of moderately reported levels of TCK, TPK and TPACK. Although the use of technology has notably increased in schools in Malaysia in general, many teachers are still unfortunately unable to integrate technology effectively into their teaching and learning process.

In the study, experienced teachers tended to rate their CK, PK and PCK significantly higher than those of novice teachers. Novice teachers rated their TK significantly higher than those of experienced teachers. As suggested by previous research on PCK, teaching experiences contribute toward a higher reported value of Content and Pedagogical Knowledge; the more years a teacher teaches, the more he would acquire content and pedagogical knowledge. Gess-Newsome (1999), Van Driel et al., (1998) and Grossman (1990) found that experienced teachers' CK, PK and PCK tended to be better as they would have more opportunities to accumulate this knowledge through their actual teaching experiences, in comparison with novice teachers who are still developing their integrative knowledge and skills.

For technology knowledge (TK), the study has revealed that novice teachers reported higher personal confidence than that of experienced teachers. These early-career teachers are more likely to be ready take time to learn about technology and integrate technology into their teaching (Jang \& Tsai, 2013) while most experienced teachers tended to be older, wiser and would have been comfortable with the instructional strategies that they have been using year in year out.

Findings of the study have alluded implications for future studies. Research on the state of teacher education at a more systemic and longitudinal perspective is recommended to inform policy and practice. All subjects offered in primary and secondary schools in Sarawak should be scrutinised, to determine the knowledge, competencies and existing practices among teachers, specifically in using technology to develop and boost the quality of learning. Such research would provide a basis in understanding how technology competencies can be addressed according to the needs, urgency, and relevance of each subject matter.

Proposed solutions for stakeholders in Education and Teacher Education in Malaysia are described below:

a. For teachers with under five years' in-service experience, professional development opportunities should focus on the inter-component knowledge (PCK, TCK, TPK and TPACK) which would harness their knowledge, skills and interest in using technology in the classroom. Creating "champions" among young teachers is a strategy to enculturate technology adoption in teaching. 
b. For teachers with under ten years' in-service experience, they make up the largest group inservice at the point of writing. The scope of professional development courses for the group should leverage on their CK, PK and PCK competencies. Training should be designed to start from the Pedagogical component, drawing on pedagogical strategies that would match various technology tools available off-the-shelf and those which require programming skills. They would benefit the most if given sufficient resources to explore and use technology for teaching, as they recorded a higher affinity toward technology knowledge.

c. For teachers with more ten years' in-service experience, their professional development opportunities should encompass their strength in Content Knowledge, and how it would be harnessed using technology tools. If they are not comfortable to learn new digital skills such as programming, their knowledge and experience in the subject content would be capitalised. Innovative learning contents could be generated collaboratively with the less-experienced teachers, to bridge the TPACK gaps between the teaching faculty.

\section{Conclusion}

Integrating technology is never about gaining mastery of technology. It is primarily about deciding the best combinations between content and pedagogy. Teaching with technology involves the use of relevant features within technology tools which best enable learning to happen. In-depth knowledge about the curriculum and syllabus are the main drivers to initiate change for development. Technology integration entails the design of the learning experience, not by the tools or quantity of use.

The study contributes to the national TPACK research, as it examined the self-reported competencies of in-service secondary school science teachers in selected parts of Sarawak. The result shows that science teachers have a high perception of their competencies of core knowledge components (CK, PK, TK) and PCK. However, there are issues for in term of knowledge to interact the technology with pedagogy and content (TCK, TPK and TPACK). More than that, in-service science teachers with their teaching experience are significantly higher in CK, PK and PCK but that teachers who had more teaching experience reported a lower level of TK.

Stakeholders such as the Ministry of Education, State Education departments and school administrators, play an essential role to initiate change. There are two suggested aspects to consider: (1). However, most science teachers have been trained and have used digital technologies in teaching Science. The training to develop a teaching skill which incorporates content knowledge, pedagogical knowledge and technological knowledge should be deliberately designed and systematically offered for all teachers at all levels. (2) training materials and resources related to understanding the combination of content, pedagogy and technology may need to be provided for experienced Science teachers so that their technology integration becomes holistic and effective in the classroom, in line with the goals for $21^{\text {st }}$-century education.

It is proposed that an elaborately designed continuous professional development initiative is offered to all Sarawak teachers, at all levels, and for every subject taught. Teacher training programmes should deliberately incorporate the TPACK model into their curriculum, to develop a timerelevant set of teaching skills among pre-service teachers. In-service teachers should be provided with materials, resources and professional development opportunities to enable them to leap forward with emerging needs to incorporate technology in the classroom.

\section{ACKNOWLEDGMENT}

The study did not receive any specific grant from any funding agency. 


\section{References}

1. Abbitt, J. T. (2011). An investigation of the relationship between self-efficacy beliefs about technology integration and technological pedagogical content knowledge (TPACK) among preservice teachers. Journal of digital learning in teacher education, 27(4), 134-143.

2. Carpenter, J., Rosenberg, J., Dousay, T., Romero-Hall, E., Trust, T., \& Kessler, A. et al. (2020). What should teacher educators know about technology? Perspectives and self-assessments. Teaching And Teacher Education, 95, 103124. DOI: 10.1016/j.tate.2020.103124

3. Chai, C. S., Koh, J. H. L., Tsai, C., \& Lee, L. W. T. (2011). Modelling primary school pre-service teachers' technological pedagogical content knowledge (TPACK) for meaningful learning with information and communication technology (ICT). Computers \& Education, 57(1), 1184-1193. https://doi.org/10.1016/j.compedu.2011.01.007

4. Chang, Y., Tsai, M., \& Jang, S. (2014). Exploring ICT use and TPACK of secondary science teachers in two contexts. US-China Education Review, 4(5), 298-311.

5. Chen, Y. H. \& Jang, S. J. (2014). The interrelationship between stages of concern and technological, pedagogical, and content knowledge: A study on Taiwanese senior high school in-service teachers. Computers in Human Behavior, 32, 79-91.

6. Cheng, S., \& Xie, K. (2018). The relations among teacher value beliefs, personal characteristics, and TPACK in intervention and non-intervention settings. Teaching And Teacher Education, 74, 98-113. DOI: 10.1016/j.tate.2018.04.014.

7. Cox, B. S., \& Graham, C. R. (2009). Diagramming TPACK in practice: Using an elaborated model of the TPACK framework to analyse and depict teacher knowledge. TechTrends, 53(5), 60-69.

8. Crawford, R. (2000). Information technology in secondary schools and its impact on training information technology teachers. Journal of Information Technology for Teacher Education, 9(2), 37-41.

9. Dhanapal, S., \& Wan, E. Z. S. (2014). A study on the effectiveness of hands-on experiments in learning Science among year four students. International Online Journal of Primary Education, 3(1), 29-40.

10.Dilworth, B. P., Donaldson, A., George, M., Knezek, D., Searson, M., Starkweather, K., Strutchens, M., Tillotson, J., \& Robinson, S. (2012). Preparing teachers for tomorrow's technologies. TechTrends, 56(4), 11-15.

11.Ghavifekr, S., \& Wan Athirah, W. R. (2015). Teaching and learning with technology: Effectiveness of ICT integration in schools. International Journal of Research in Education and Science (IJRES), 1(2), 175-191.

12.Graham, C. R., Burgoyne, N., Cantrell, P., Smith, L., Clair, L. S., \& Harris, R. (2009). TPACK development in science teaching: Measuring the TPACK confidence of in-service science teachers. TechTrends, 53(5).

13.Guzey, S. S., \& Roehrig, G. H. (2009). Teaching Science with technology: Case studies of science teachers' development of technology, pedagogy, and content knowledge. Contemporary Issues in Technology and Teacher Education, 9(1), 25-45. https://doi.org/10.1007/s10956-008-9140-4

14. Hasniza, N., \& Tengku Faekah, T. A. (2016). Validation of a technological pedagogical content knowledge instrument in a Malaysian secondary school context. Malaysian Journal of Learning and Instruction, 13, 1-24.

15. Hew, K. F., \& Brush, T. (2007). Integrating technology into K-12 teaching and learning: current knowledge gaps and recommendations for future research. Educational Technology Research and Development, 55(3), 223-252. https://doi.org/10.1007/s11423-006-9022-5

16.Jaipal-Jamani, K., \& Figg, C. (2015). A case study of a TPACK-based approach to teacher professional development: Teaching science with blogs. Contemporary issues in technology and teacher education, 15(2), 161-200. 
17.Jang, S. J., \& Tsai, M. F. (2013). Exploring the TPACK of Taiwanese secondary school science teachers using a new contextualised TPACK model. Australasian Journal of Educational Technology, 29(4), 566-580.

18.Jang, S., \& Tsai, M. (2012). Exploring the TPACK of Taiwanese elementary mathematics and science teachers with respect to the use of interactive whiteboards. Computers \& Education, 59(2), 327338. https://doi.org/10.1016/j.compedu.2012.02.003

19.Koehler, Mathew J., Shin, T. S., \& Mishra, P. (2012). How do we measure TPACK? Let me count the Ways. In Educational Technology, Teacher Knowledge, and Classroom Impact: A Research Handbook on Frameworks and Approaches (pp. 16-31).

20.Koehler, Matthew J., \& Mishra, P. (2009). What is technological pedagogical content knowledge? Contemporary Issues in Technology and Teacher Education, 9(1), 60-70.

21.Koehler, Matthew J, \& Mishra, P. (2005). Teachers Learning Technology by Design. Journal of Computing in Teacher Education, 21(3), 94-102.

22.Koh, J. H. L., Chai, C. S., \& Tsai, C.-C. (2014). Demographic factors, TPACK constructs, and teachers' perceptions of constructivist-oriented TPACK. Educational Technology \& Society, 17(1), 185-196.

23.Lee, M.-H., \& Tsai, C.-C. (2010). Exploring teachers' perceived self-efficacy and technological pedagogical content knowledge with respect to educational use of the world wide web. Instructional Science, 38(1), 1-21. https://doi.org/10.1007/s11251-008-9075-4

24.Liang, J., Chai, C. S., Koh, J. H. L., Yang, C.-J., \& Tsai, C.-C. (2013). Surveying in-service preschool teachers' technological pedagogical content knowledge. Australasian Journal of Educational Technology, 29(4), 581-594.

25.Lin, T.-C., Tsai, C.-C., Chai, C. S., \& Lee, M.-H. (2013). Identifying science teachers' perceptions of technological pedagogical and content knowledge (TPACK). Journal of Science Education and Technology, 22(3), 325-336. https://doi.org/10.1007/s10956-012-9396-6

26. Mohamad, Fitri Suraya (2010). Investigating beliefs and evidence of Technological Pedagogical Content Knowledge (TPCK) in the training of teachers for educational technology in Malaysian universities (Doctoral dissertation, Institute of Education, University of London).

27. Muhammad Abd Hadi, B., \& Phang, F. A. (2012). Technological pedagogical and content knowledge among undergraduate education degree students at Universiti Teknologi Malaysia. Procedia-Social and Behavioral Sciences, 56, 432-440.

28.Niess, M.L. (2005). Preparing teachers to teach Science and mathematics with technology: Developing a technology pedagogical content knowledge. Teaching and Teacher Education, 21(5), 509-523.

29.Niess, Margaret L, Ronau, R. N., Shafer, K. G., Driskell, S. O., Harper, S. R., Johnston, C., \& Browning, C. (2009). Mathematics teacher TPACK standards and development model. Contemporary Issues in Technology \& Teacher Education, 9(1), 4-24.

30.Nurul Ain, H., \& Zaleha, I. (2008). Pengetahuan teknologi pedagogi kandungan guru pelatih matematik sekolah menengah. Seminar Kebangsaan Pendidikan Sains Dan Matematik, 1-14.

31.Olofson, M., Swallow, M., \& Neumann, M. (2016). TPACKing: A constructivist framing of TPACK to analyse teachers' construction of knowledge. Computers \& Education, 95, 188-201. DOI: 10.1016/j.compedu.2015.12.010

32.Pamuk, S. (2012), understanding pre-service teachers' technology use through the TPACK framework. Journal of Computer Assisted Learning, 28: 425-439. DOI:10.1111/j.13652729.2011.00447.x

33.Schmidt, D. A., Baran, E., Thompson, A. D., Mishra, P., Koehler, M. J., \& Shin, T. S. (2009). Technological pedagogical content knowledge (TPACK): The development and validation of an assessment instrument for pre-service teachers. Journal of Research on Technology in Education, 42(2), 123-149.

34.Shulman, L. S. (1986). Those Who Understand: Knowledge Growth in Teaching. Educational Research, 15(2), 4-14.

35.Shulman, L. S. (1987). Knowledge and teaching. Foundations of the new reform. Harvard Educational Review, 57(1), 1-22. 
36.Teo, T., \& Hwee, J. L. K. (2010). Assessing the dimensionality of computer self-efficacy among preservice teachers in Singapore: A structural equation modelling approach. International Journal of Education and Development Using Information and Communication Technology, 6(3), 7-18.

37.Tunku Badariah, T. A. (2014). Between School Factors and Teacher Factors : What inhibits Malaysian science teachers from using ICT ? The Malaysian Online Journal of Educational Technology, 2(1), 110.

38.Wachira, P., \& Keengwe, J. (2010). Technology integration barriers: Urban school mathematics teachers perspectives. Journal of Science Education and Technology, 20(1), 17-25. https://doi.org/10.1007/s10956-010-9230-y 